\title{
OSTEOSARKOMOS DIAGNOSTIKOS IR GYDYMO IŠŠŪKIAI. KLINIKINIS ATVEJIS
}

\author{
Mindaugas Stravinskas ${ }^{1}$, Vètra Markevičiūtè ${ }^{1}$, Pranciškus Bakutis ${ }^{2}$ \\ ${ }^{1}$ Lietuvos sveikatos mokslu universiteto Ortopedijos-traumatologijos klinika, \\ ${ }^{2}$ Lietuvos sveikatos moksly universiteto Medicinos akademijos Medicinos fakultetas
}

Raktažodžiai: osteosarkoma, klinikinis atvejis, pasikeitusi diagnozè.

\begin{abstract}
Santrauka
Osteosarkoma - dažniausias agresyvus pirminis piktybinis kaulinis navikas, dažniausiai pasireiškiantis tarp paauglių, tačiau nustatytas antras pasireiškimo pikas tarp vyresnio amžiaus žmonių (1). Naviko etiologija nèra tiksliai žinoma, galimi ịvairūs predisponuojantys rizikos veiksniai, tačiau dažniausia lokalizacija labiausiai augančiose kaulų dalyse ir pasireiškimo amžiaus skirtumai tarp paauglių berniuku ir mergaičiu leidžia įtarti, jog naviko atsiradimas susijęs su greitu augimu ir hormoniniu aktyvumu. Dažniausias naviko simptomas - skausmas, kuris gali pažadinti iš miego naktị, taip pat dažnai susijęs su patirta trauma. Labai svarbi tiksli naviko diagnozé, todèl rekomenduojama atlikti naviko židinio MRT bei krūtinès ląstos, pilvo, dubens ir stuburo KT naviko išplitimui vertinti. Iki $1970 \mathrm{~m}$. pagrindinis osteosarkomos gydymo būdas - naviko pažeistos galūnès amputacija, kurių rezultatas - 5 metų išgyvenamumas - siekè vos 10 proc. Paskutiniu metu plètojant indukcinès ir adjuvantinès chemoterapijos galimybes ir atliekant plačią naviko rezekciją pasiektas 60-70 proc. 5 metų išgyvenamumo rodiklis.
\end{abstract}

\section{Ivadas}

Osteosarkoma - dažniausias pirminis piktybinis kaulu navikas ir trečias pagal dažnumą navikas tarp vaikų ir paauglių (5-19 m.), turintis antrą susirgimo viršūnę vyresniame amžiuje (vyresniems nei $60 \mathrm{~m}$.) (1) Navikas prasideda iš supiktejjusių mezenchiminių ląstelių, kurios sukelia osteoidinio audinio ir nebrandžių osteoblastų hiperprodukciją. Per metus nustatoma 3:1 000000 gyventojų naujų atvejų. Etiologija nèra žinoma - vaikams dažniausiai prasideda sporadiškai, nors yra nustatyta šeiminių osteosarkomų atvejų.
Galimi nulemiantys rizikos veiksniai - ankstesnè jonizuojanti radiacija ar chemoterapija, Pedžeto liga ar kiti gerybiniai kaulinio audinio pažeidimai, ryšys su genetiniais sindromais (RB1 geno, susijusio su paveldima retinoblastoma) ar TP53 geno (susijusio su Li-Fraumeni sindromu, mutacija (2). Nors etiologija nèra aiški, tačiau skirtingos amžiaus grupès pagal osteosarkomos dažnumą tarp paauglių mergaičių (10-14 m.) ir berniukų (15-19 m.) ir vèžio lokalizacija labiausiai augančiose kaulo dalyse suponuoja, jog ịtaką gali daryti greitas augimas ir hormoninis aktyvumas, nors atlikti tyrimai nenurode ryšio su augimo ar vystymosi faktoriais (3). Osteosarkomos lokalizacija yra ilgujų kaulų metafizejje, dažniausiai - distalinėje šlaunikaulio (43 proc.), proksimalinejje blauzdikaulio (23 proc.) ar žasto (10 proc.) dalyse (4).

Osteosarkomos gali būti pirminès ir antrinès. Jauname amžiuje būdinga pirminè osteosarkoma, kuri gali būti skirstoma ị centrinę ar intramedulinę ir paviršinę, tuo tarpu antrinè osteosarkoma būdinga vyresniame amžiuje ir dažniausiai susijusi su antrine navikine degeneracija (5). Osteosarkoma skirstoma ị subtipus pagal lokalizaciją kaule, ląstelių diferenciaciją ir morfologinę kilmę (6).

Plačiau norime aptarti du tipus.

Gerai diferencijuota centrinè osteosarkoma (LGCOS) sudaro tik $1,2 \%$ visų osteosarkomų (7). Šis osteosarkomų tipas labai retas, bet turi gerą prognozę, kai yra atliekamas radikalus naviko pašalinimas. Chemoterapija ar spindulinè terapija nèra indikuotina. Tinkamas gydymas turi labai gerą prognozę: 5 ir 10 metų išgyvenamumas atitinkamai $90 \%$ ir $85 \%$. Autoriai nurodo, kad 15\% LGCOS gali diferencijuotis i aukšto piktybiškumo osteosarkomą, įskaitant ir metastazavimo galimybę (8).

Osteoblastinè osteosarkoma sudaro iki 50 proc. blogai diferencijuotos centrinès osteosarkomos atvejų (dažniausias osteosarkomos tipas) (9). Galimas skirtingas atsakas ị chemoterapiją, lemiantis metastazinès ligos vystymąsi. Nors gydymas nuo kitų osteosarkomos tipų iš esmès nesiskiria, tačiau svarbi gera citologinè diferenciacija nuo chondroblas- 
tinès ir mažų ląstelių osteosarkomos, kurios turi blogesnị 5 metų išgyvenamumą ir didesnį lokalaus recidyvo dažnį.

Diagnostika. Simptomai pasireiškia lokaliu skausmu naviko augimo vietoje, kuris dažniausiai susijęs su sportu ar trauma ir yra lydimas lokalaus patinimo bei greta esančiu sąnarių judesių amplitudès sumažèjimo. Pagrindinis skausmo požymis - skausmas dažniau pasireiškia naktį, pažadina iš miego (10). Navikas gali pasireikšti ir nespecifiniais bendraisiais simptomais - svorio kritimu, karščiavimu, naktiniu prakaitavimu (11).

Diagnostika prasideda nuo dviejų krypčių rentgenogramos, kurioje galima matyti kaulo destrukciją, tranzitinę zoną, periosto reakciją, minkštujų audinių komponentą ar naviko kalcifikaciją. Itarus piktybinį procesą, rekomenduojama atlikti MRT, apimant visą kaulą ir proksimalinį bei distalinị sąnarius, kuris nustato naviko išplitimą. Naviko metastazių išplitimui vertinti rekomenduojama krūtinès ląstos, pilvo, dubens ir stuburo KT. Jei yra galimybe, atliekama vieno fotono emisijos KT (SPEKT) ir pozitronų emisijos tomogra-

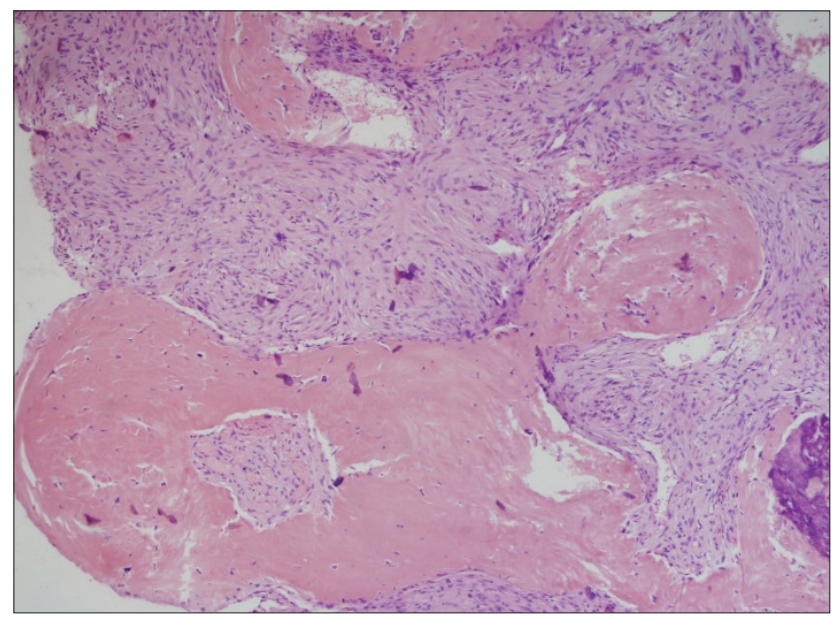

1 pav. Histologinis tyrimas - intraosalinė gerai diferencijuota osteosarkoma (G1 stadija).

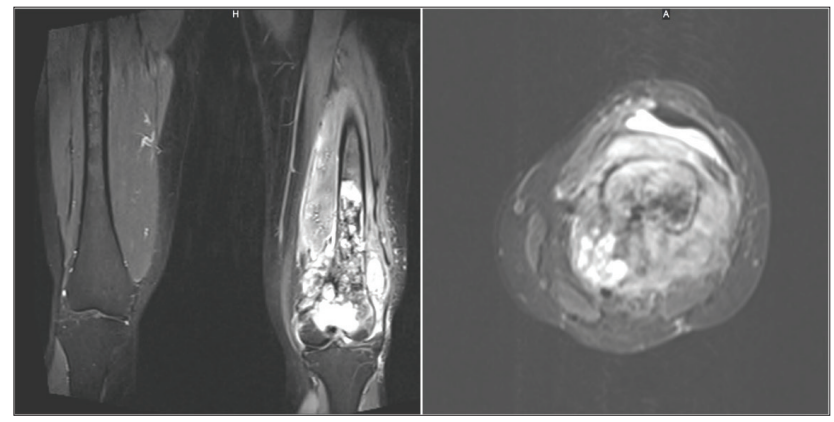

2 pav. Skubos tvarka atliktas priešoperacinis kairiosios šlaunies MRT. fija (PET), kuriuose matomi židinių kiekiai, taip pat galimas naviko piktybiškumo vertinimas.

Osteosarkomos diagnozė nustatoma histologinio tyrimo metu, tiriant medžiagą paimtą biopsijos metu. Biopsijos dažniausiai atliekamos specialiomis trepano kaulų adatomis, operacineje, rentgeno kontroleje.

Gydymas. Iki 1970 m. pagrindinis osteosarkomos gydymo principas buvo pažeistos galūnès amputacija, tačiau penkerių metų išgyvenamumas nesiekè 10 proc. ir dauguma pacientų mirdavo dèl naviko išplitimo, dažniausiai ị plaučius (11). Tačiau per pastaruosius dešimtmečius indukcinès ir adjuvantinès chemoterapijos protokolų plètojimas leidžia gydyti naviką išsaugant pažeistą galūnę su 60-70 proc. siekiančiu 5 metų išgyvenamumu (12). Šiuo metu yra daug skirtingų osteosarkomos gydymo būdų, tačiau geriausiu rezultatu pasižymi plati naviko rezekcija su kaulo rekonstrukcija naudojant endoprotezą arba alogeninį transplantatą kartu su ar be chemoterapijos, priklausomai nuo naviko tipo.

\section{Klinikinis atvejis}

2012 metais 43 metų moteris kreipèsi ị šeimos gydytoją dèl skausmo kairio šlaunikaulio apatiniame trečdalyje, kuris vargino apie 4 mènesius. Skausmui malšinti paciente vartojo nesteroidinius vaistus nuo uždegimo, tačiau efekto nebuvo. Objektyvaus tyrimo duomenimis nustatyta kairio kelio sąnario fleksija iki 20 laipsnių (sveikame kelio sąnaryje - iki 135 laipsniu). Apčiuopos metu skausmingumas nenustatytas, periferiniai limfmazgiai neapčiuopiami. Atlikus kairio šlaunikaulio apatinès dalies rentgenogramą, buvo stebima kaulo destrukcija, periosto reakcija. Detalesniam ištyrimui buvo atlikta kaulų scintigrafija ir kairio šlaunikaulio apatinès dalies SPEKT, kuriuose buvo matomas intensyvus radioindi-

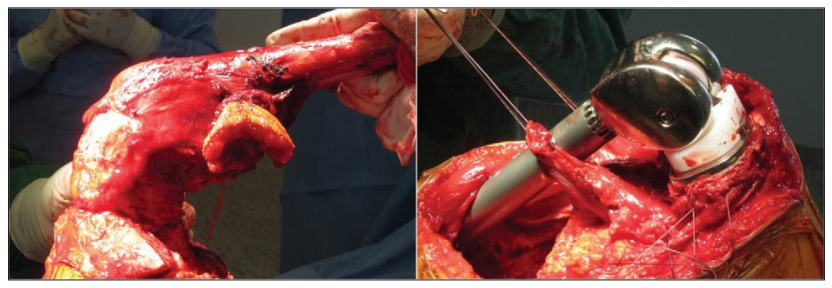

3 pav. Atlikta ekstraartikulinè naviko rezekcija bei implantuotas segmentinis modulinis endoprotezas.

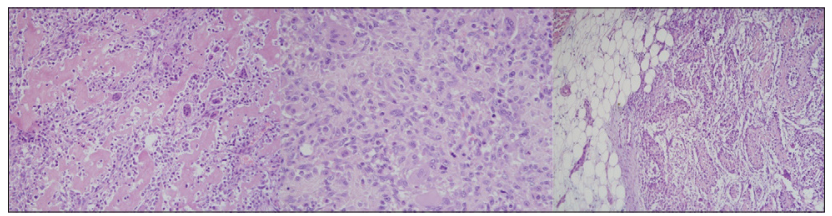

4 pav. Pooperacinès medžiagos histologinis tyrimas - G3 diferenciacijos osteosarkoma. 
katoriaus telkimasis kairio šlaunikaulio diafizès apatiniame trečdalyje, siekiantis metafizinę sritį. SPEKT vaizduose intensyvaus radioindikatoriaus telkimosi sritis projektavosi anatomiškai. KT vaizduose buvo matomas darinys, kuris pagal matomą vaizdą buvo labiausiai panašus ị enchondromą, tačiau tik apatineje šlaunikaulio dalyje. Intensyviausio radioindikatoriaus telkimosi srityje žievinis kaulo sluoksnis išplonejja ir vietomis nutrūksta, todèl nebuvo galima atmesti piktybinio proceso diagnozès. Kituose kauluose patologiniu radioindikatoriaus telkimosi židinių nestebèta. Diagnozès patikslinimui buvo atlikta tumoro biopsija, kurios histologinio tyrimo atsakyme formuota išvada - intraosalinè gerai diferencijuota osteosarkoma (G1 piktybiškumo) (1 pav.).

Ligos išplitimui įvertinti buvo atliktas krūtinès, pilvo ir dubens organų KT tyrimas, ligos išplitimas nestebetas. Pacientė buvo pradèta ruošti operaciniam gydymui: suplanuota operacija, užsakytas specialus onkologinis šlaunikaulio apatinès dalies protezas. Operacijos planavimas truko 7 savaites: gauti specialaus onkologinio protezo komponentai bei Valstybinès ligonių kasos (VLK) patvirtinimas dẻl protezo finansavimo pagal numatytą tvarką. Stacionarizavus pacientę operaciniam gydymui, buvo stebètos labai padidejusios kairio kelio ir šlaunies apimtys, dinamikoje stiprèjantis skausmingumas. İtariant naviko progresavimą, skubos tvarka atliktas kairès šlaunies ir kelio sąnario MRT, kuriame kairiojo šlaunikaulio distalineje dalyje buvo matomi apie 15 $\mathrm{cm}$ kaulo destrukciniai pakitimai, prasidedantys apie $1 \mathrm{~cm}$ virš sąnarinio paviršiaus. Taip pat stebėtas naviko įaugimas i kelio sąnarị. Apatineje šlaunikaulio dalyje, apie $9 \mathrm{~cm}$ ilgio srityje, navikas supo šlaunikauli cirkuliarai (navikas apie 8 $\mathrm{cm}$ skersmens) ir infiltravo keturgalvị šlaunies raumenị apie $20 \mathrm{~cm}$ ilgyje virš girnelès (2 pav.).

Buvo nustatytas labai didelis ir greitas naviko progresavimas ekstraosaliai. Vaizduose buvo stebimas gresiančio patologinio šlaunikaulio lūžio vaizdas. I̦vertinus ligos progresavimo greiț (tiek kliniškai, tiek radiologiškai), ịtarta, jog gali būti pasikeitusi naviko morfologija, kadangi mažo laipsnio centrinei osteosarkomai greitas progresavimas nèra būdingas. Dèl gresiančio lūžio ir labai staigaus ligos progresavimo nutarta neatideti operacinio gydymo - iškart atlikti naviko rezekciją, be pakartotinès biopsijos ir detalesnio ištyrimo. İvykus patologiniam lūžiui, navikinès ląstelès per kraujosruvą išnešiojamos ị visus aplinkinius audinius ir bendra išgyvenamumo prognoze pablogeja iki 10 kartų. Po 2,5 mènesio nuo pirmo kreipimosi ị šeimos gydytoją (1,5 mènesio nuo histologinio ligos patvirtinimo) atlikta šlaunikaulio distalinès dalies ir viso kelio sąnario ekstraartikulinè rezekcija. Ekstraartikulinė rezekcija - tai operacijos metodas, kai kaulinis navikas, apimantis greta esantị sąnarį, pašalinamas kartu su visais aplinkiniais minkštaisiais audiniais, laikantis visų onkologinių principų, radikaliomis ribomis neatveriant kelio sąnario. Kelio sąnarys buvo šalinamas su visa kapsule, raiščiais, girnelès kremzliniu paviršiumi, blauzdikaulio proksimaliniu sąnariniu paviršiumi. Tokio tipo rezekcijos techniškai sudėtingos, tačiau užtikrina operacinès ložès ablastiškumą (užteršimo pavienèmis navikinèmis ląstelèmis dèl netiesioginio kontakto su naviku nebuvimą). Operacijos metu pavyko išsaugoti šlaunies kraujagysles ir nervus, buvo implantuotas cementinis segmentinis modulinis endoprotezas (3 pav.).

Pooperacinès medžiagos histologinis tyrimas paneigè prieš operaciją formuotą klinikinę diagnozę. Gautas atsakymas - osteoblastiné osteosarkoma pT2NxMxR0 G3 (4 pav.) Pacientei nustačius G3 (aukšto piktybiškumo) diferenciacijos laipsnio osteosarkomą, nuspręsta taikyti chemoterapiją pagal Euroboss I gydymo protokolą doksorubicinu, cisplatina ir ifosfamidu. Šis protokolas naudojamas Europoje pacientams per 40 metul.

Chemoterapija buvo taikyta 24 savaites, chemoterapijos metu dozè mažinta 10-20\% dèl nepageidaujamų reakcijų: III $^{\mathrm{o}}$ trombocitopenijos, $\mathrm{IV}^{\mathrm{o}}$ neutropenijos. Chemoterapijos metu febrilinès neutropenijos epizodų nebuvo stebèta. 11 mèn. po operacijos nuspręsta taikyti spindulinès terapijos gydymą i pooperacinę naviko ložę, iš viso realizuota $60 \mathrm{~Gy}$ / 30 fr švitinimo dozè.

Pasikeitus diagnozei ir koregavus gydymo planą, paciente išvengė su naviku susijusių komplikacijų. Pacientė stebima pagal LSMUL KK patvirtintą sarkomų protokolą BMR ir KT vietiškai, taip pat viso kūno skenavimais (pradžioje kas 6 menesius, vèliau kas 1 metus). Ligos lokalus recidyvas ar atokios metastazės šiuo metu nenustatytos. Pacientė vaikšto be papildomų atramos priemonių, stebima nedidelè kairès šlaunies ir blauzdos raumenų atrofija, susilpnejjusi kojos jèga. Judesiai per kelio sąnari labai geri, ekstenzija pilna, fleksija galima iki 100 laipsnių, pastoviai dirba lengvą fizinį darbą. Duomenų dèl mechaninių ar infekcinių endoprotezo komplikacijų nèra. Funkcinis rezultatas puikus, ivvertinimas pagal MSTS (Musculoskeletal tumor society scoring system/kaulų ir raumenų sistemos navikų asociacijos vertinimo sistemą) yra 27 iš 30 galimų balų - labai aukštas.

\section{Diskusija}

Atvejis sudètingas, kadangi prieš operaciją buvo ịtariama intraosalinè osteosarkoma, kuri buvo diferencijuota su enchondroma. Atlikus biopsijas histologiniame tyrime buvo nustatyta G1 diferenciacijos laipsnio osteosarkoma, pagal Nacionalinio visuotinio vèžio tinklo (NCCN - National Comprehensice Cancer Network) rekomendacijas pacientei buvo numatytas operacinis gydymas be chemoterapijos, atliekant plačią naviko rezekciją. Pooperacinis naviko his- 
tologinis tyrimas parodè G3 diferenciacijos laipsnio naviką. Siekiant sumažinti atokiąsias metastazes, naviką ribojančių aplinkinių audinių edeminę reakciją ir galimas paslèptas metastazes edemos zonoje, nustačius osteoblastinę osteosarkomą taikoma neadjuvantinè/iniciacinè chemoterapija. EURO-B.O.S.S 2018 metais atliktoje studijoje, kurioje pacientų, sergančių didelio piktybiškumo nemetastazavusia osteosarkoma, gydymo metu naudojant chemoterapiją pagal Euroboss protokolą, pasiektas 5 metų išgyvenamumas $66 \%$ (13). Blogiau diferencijuoti navikai yra linkę metastazuoti, dažniausiai ị plaučius, todèl osteosarkomos diferenciacijos laipsnis yra stipriai susijęs su naviko metastazių rizika ir prognoze (14). Bendras 5 metų išgyvenamumas sergant osteosarkoma suaugusiems (25-59 metų amžiaus grupè) yra apie 60 proc. (15). Didejantis navikas stipriai padidina patologinių lūžių riziką, kurie yra susiję su padidejusia lokalaus recidyvo rizika ir sumažejjusiu išgyvenamumu, palyginus su pacientais, kuriems neivvyko patologinis lūžis (16).

Diskutuojama, ar neoadjuvantinè chemoterapija sumažina ligos recidyvo dažni, tačiau žinoma, jog tai turi teigiamą ịtaką bendram paciento išgyvenamumui. Chemoterapijos taikymas leidžia vertinti chemoterapijos poveiki i naviką, po operacijos nustatant naviko nekrozès laipsnị. Tai suteikia daug informacijos vertinant naviko prognozę (17). Taikant neadjuvantinę chemoterapiją dažnai sumažèja naviką ribojančių audinių edema, dèl to pagerèja rezekcinès ribos. Rezekcinès ribos šalinant naviką skirstomos ị kelis tipus: intražidininè (einant per naviką), ribinès/kraštinès, plati arba radikali (amputacija) (18). Literatūroje pateikiama daug tyrimų, kokias rezekcines ribas pasirinkti, tačiau rezekcinių kraštų vertinimas išlieka prieštaringas. 2012 metais Skandinavijoje atliktame tyrime, kuriame buvo vertinamas recidyvu dažnis rezekuojant sarkomą mažiau nei $2 \mathrm{~mm}$ rezekcinėmis ribomis ir rezekuojant navikus su 2-20 mm rezekcinemis ribomis, statiškai reikšmingas skirtumas vertinant ligos recidyvą nebuvo stebètas (19). Kitame Japonijoje atliktame tyrime, kuriame dalyvavo 837 operuoti pacientai dèl osteosarkomos, geriausias priešoperacinio gydymo veiksmingumas buvo nustatytas, kai rezekuota platesnèmis nei $20 \mathrm{~mm}$ pločio rezekcinėmis ribomis (20), tačiau ankščiau minètame tyrime nepavyko nustatyti skirtumo tarp ligos recedyvų vertinant mažesnes nei $2 \mathrm{~mm}$ ar didesnes nei $2 \mathrm{~mm}$ rezekcines ribas (21). Literatūroje pateikiamuose tyrimuose akcentuojama, kad reikia vertinti navikų recidyvų dažnį atsižvelgiant ne tik ị rezekcines ribas, bet ir naviko atsaką i chemoterapiją (geras atsakas ị chemoterapiją nustatomas, kai naviko nekrozès laipsnis yra per 90 proc.). Statistiškai geriausią prognozę turi pacientai, kai naviko rezekcinès ribos yra daugiau kaip $2 \mathrm{~mm}$ ir naviko nekrozès laipsnis po chemoterapijos yra ne mažesnis nei 90 proc. (22).
Pagrindinis gydymas diagnozavus distalinės šlaunikaulio dalies osteosarkomą yra plati naviko rezekcija su kaulo rekonstrukcija naudojant endoprotezą arba alogeninį transplantatą kartu su ar be chemoterapijos, priklausomai nuo naviko diferenciacijos laipsnio (23). Endoprotezai yra pirmo pasirinkimo pooperacinių defektų rekonstrukcijos metodas esant didelių sąnarinių defektų atstatymui. Jie greičiau padeda atstatyti pažeistos vietos funkciją, tačiau yra brangūs, sunku pritvirtinti minkštuosius audinius, po operacijos ilgą laiką ribojamas krūvis, galimos protezo lūžio (12-30 proc.), infekcijos (12-20 proc.), išklibimo 6-35 proc.) komplikacijos (24).

Labai mažam skaičiui pacientų sarkoma pažeidžia ir plinta ị kelio sąnario vidų, dèl to yra reikalinga ekstraartikulinè kelio sąnario rezekcija (25). Ši operacinè technika yra ypač sudètinga. Indikacijos šiam operacijos tipui yra ankščiau atliktos kelio sąnario procedūros, kurių metu buvo užterštas kelio sąnarys navikinėmis ląstelèmis, apimantis kryžminius kelio sąnario raiščius, naviko augimas, patologinis lūžis, kurio metu navikinèmis ląstelemis užterštas kelio sąnarys, navikas, ịtraukiantis kelio sąnarị, ar jei sarkoma yra nugarinejje kelio sąnario dalyje ir įtraukia dvilypio raumens galvas (26). Galimi du pagrindiniai ekstraartikulinès kelio sąnario rezekcijos variantai: ekstraartikulinè kelio sąnario rezekcija išsaugant tiesiamajj kelio sąnario mechanizmą ir antras variantas - pašalinant ir tiesiamąj̣ kelio sąnario mechanizmą, panaudojant dvilypio raumens lopą (27). Atliktame tyrime, kuriame dalyvavo pacientai, kuriems dèl osteosarkomos buvo atlikta ekstraartikulinè kelio sąnario rezekcija, nustatyta, jog visi pacientai turejo pilną ekstenziją, tačiau fleksijos vidurkis buvo $88^{\circ}\left(65^{\circ}-120^{\circ}\right)(26)$, todèl vertinant mūsų klinikinio atvejo rezultatus pacientei išliko labai gera kelio funkcija.

\section{Išvados}

Osteosarkoma pasižymi didele įvairove, literatūroje aprašoma atvejų, kuomet gerai diferencijuotos osteosarkomos metu randama blogai diferencijuoto naviko vietu, taip pat mūsų aprašytas iki gyvybei pavojingos stadijos atvejis, kuomet vyko greitas ligos progresavimas kelias organų sistemas galinčios apimti ligos, kurią reikia nedelsiant agresyviai gydyti. Kiekvienam pacientui gydymo planas turètu būti sudaromas individualiai, turi vykti nuolatinis paciento skundų ir klinikinių požymių stebèjimas. Gydymas, atliekant plačią naviko eksciziją yra veiksmingas taikant kartu ar be chemoterapijos, priklausomai nuo osteosarkomos tipo.

\section{Literatūra}

1. Simpson E, Brown HL. Understanding osteosarcomas. J Am Acad Physician Assist 2018; 31(8):15-19.

https://doi.org/10.1097/01.JAA.0000541477.24116.8d 
2. Zhang J, Walsh MF, Wu G, Edmonson MN, Gruber TA, Easton J. et al. Germline mutations in predisposition genes in pediatric cancer. N Engl J Med 2015; 373:2336-46.

https://doi.org/10.1056/NEJMoa1508054

3. Troisi R, Masters MN, Joshipura K, Douglass C, Cole BF, Hoover RN. Perinatal factors, growth and development and osteosarcoma risk. Br J Cancer 2006; 95(11):1603-7. https://doi.org/10.1038/sj.bjc.6603474

4. Isakoff MS, Bielack SS, Meltzer P, Gorlick R. Osteosarcoma: current treatment and a collaborative pathway to success. J Clin Oncol 2015; 33(27):3029-35. https://doi.org/10.1200/JCO.2014.59.4895

5. Marchiori DM. Bone Tumors and Related Diseases [Internet]. Third Edit. Clinical Imaging: With Skeletal, Chest, \& Abdominal Pattern Differentials: Third Edition. Elsevier Inc.; 2013. 811-924 p. Available from: http://dx.doi.org/10.1016/B978-0323-08495-6.00013-0

https://doi.org/10.1016/B978-0-323-08495-6.00013-0

6. Kundu Z. Classification, imaging, biopsy and staging of osteosarcoma. Indian J Orthop [Internet]. 2014; 48(3):238. Available from: http://www.ijoonline.com/text.asp?2014/48/3/238/132491 https://doi.org/10.4103/0019-5413.132491

7. Ostrowski ML, Johnson ME, Smith PD, Chevez-Barrios P, Spjut HJ. Low-grade intraosseous osteosarcoma with prominent lymphoid infiltrate. Arch Pathol Lab Med 2000; 124:868-871.

8. Gilg MM, Liegl B, Wibmer C, Maurer-Ertl W, Leithner A. Central low-grade osteosarcoma with an unusual localization in the diaphysis of a 12-year old patient. Radiol Oncol 2013; 47(2):192-6.

https://doi.org/10.2478/raon-2013-0015

9. Sathiyamoorthy S, Ali SZ. Osteoblastic osteosarcoma: Cytomorphologic characteristics and differential diagnosis on fineneedle aspiration. Acta Cytol 2012; 56(5):481-6.

https://doi.org/10.1159/000339196

10. Ene R, Sinescu RD, Ene P, Popescu D, Cîrstoiu MM, Cîrstoiu FC. Proximal tibial osteosarcoma in young patients: Early diagnosis, modular reconstruction. Rom J Morphol Embryol 2015; 56(2):413-7.

11. Newman RK, Johnson JT. Approach to diagnosis and treatment. Postgrad Med 2016; 68(2):184-91.

https://doi.org/10.1080/00325481.1980.11715521

12. Faisham WI, Mat Saad AZ, Alsaigh LN, Nor Azman MZ, Kamarul Imran M, Biswal BM. et al. Prognostic factors and survival rate of osteosarcoma: A single-institution study. Asia Pac J Clin Oncol 2017; 13(2):e104-10.

https://doi.org/10.1111/ajco.12346

13. Ferrari S, Bielack SS, Smeland S, Longhi A, Egerer G, Sundby Hall K. et al. EURO-B.O.S.S.: A European study on chemotherapy in bone sarcoma patients aged over 40: Outcome in primary high grade osteosarcoma. Tumori 2018; 104(1):30-6. https://doi.org/10.5301/tj.5000696
14. Bielack SS, Kempf-Bielack B, Delling G, Exner GU, Flege S, Helmke K. et al. Prognostic factors in high grade osteosarcoma of the extremities or trunk: an analysis of 1,702 Patients Treated on Neoadjuvant Cooperative Osteosarcoma Study Group Protocols. J Clin Oncol [Internet]. 2002; 20(3):776-90. https://doi.org/10.1200/JCO.2002.20.3.776

15. Mirabello L, Troisi RJ, Savage SA. Osteosarcoma incidence and survival rates from 1973 to 2004: Data from the surveillance, epidemiology, and end results program. Cancer 2009; 115(7):1531-43.

https://doi.org/10.1002/cncr.24121

16. Dickey ID, Scully SP. Pathologic fracture in osteosarcoma: A review. Minerva Ortope Traumatol 2002; 53(4):187-93.

17. Goorin AM, Schwartzentruber DJ, Devidas M, Gebhardt MC, Ayala AG, Harris MB. et al. Presurgical chemotherapy compared with immediate surgery and adjuvant chemotherapy for nonmetastatic osteosarcoma: Pediatric Oncology Group Study POG-8651. J Clin Oncol 2003; 21(8):1574-80.

https://doi.org/10.1200/JCO.2003.08.165

18. Casali PG, Abecassis N, Aro HT, Bauer S, Biagini R, Bielack S. et al. Soft tissue and visceral sarcomas: ESMO-EURACAN Clinical Practice Guidelines for diagnosis, treatment and follow-up. Ann Oncol 2018; 29(4):268-269.

https://doi.org/10.1093/annonc/mdy321

19. Trovik CS, Skjeldal S, Bauer H, Rydholm A, Jebsen N. Reliability of margin assessment after surgery for extremity soft tissue sarcoma: the ssg experience. Sarcoma 2012; 2012:1-5. https://doi.org/10.1155/2012/290698

20. Li X, Moretti VM, Ashana AO, Lackman RD. Impact of close surgical margin on local recurrence and survival in osteosarcoma. Int Orthop 2012; 36(1):131-7.

https://doi.org/10.1007/s00264-011-1230-x

21. Bispo Júnior RZ, Camargo OP de. Prognostic factors in the survival of patients diagnosed with primary nonmetastatic osteosarcoma with a poor response to neoadjuvant chemotherapy. Clinics 2010; 64(12):1177-86. https://doi.org/10.1590/S1807-59322009001200007

22. Jeys LM, Thorne CJ, Parry M, Gaston CLL, Sumathi VP, Grimer JR. A novel system for the surgical staging of primary high grade osteosarcoma: the Birmingham classification. Clin Orthop Relat Res 2017; 475(3):842-50. https://doi.org/10.1007/s11999-016-4851-y

23. Wilke BK, Cooper AR, Gibbs CP, Scarborough MT, Spiguel AR. Long-term functional outcomes of distal femoral replacements compared to geographic resections for parosteal osteosarcomas of the distal femur. Iowa Orthop J 2018; 38:177-81.

24. Bickels J, Wittig JC, Kollender Y, Henshaw RM, Kellar-Graney KL, Meller I. et al. Distal femur resection with endoprosthetic reconstruction. Clin Orthop Relat Res 2004; 400(400):225-35. https://doi.org/10.1097/00003086-200207000-00028

25. Dürr HR, Bakhshai Y, Rechl H, Tunn P-U. Tumor resektion: Wie weit ist weit genug?Resection margins in bone tumors: 
what is adequate? Unfallchirurg 2014; 117(7):593-9. https://doi.org/10.1007/s00113-013-2475-1

26. Zwolak P, Kühnel SP, Fuchs B. Extraarticular knee resection for sarcomas with preservation of the extensor mechanism: surgical technique and review of cases. Clin Orthop Relat Res 2011; 469(1):251-6. https://doi.org/10.1007/s11999-010-1359-8

27. Capanna R, Scoccianti G, Campanacci DA, Beltrami G, De Biase P. Surgical technique: extraarticular knee resection with prosthesis proximal tibia extensor apparatus allograft for tumors invading the knee. Clin Orthop Relat Res 2011; 469(10):2905-14.

https://doi.org/10.1007/s11999-011-1882-2

\section{OSTEOSARCOMA: DIAGNOSTIC AND TREATMENT CHALLENGES. CASE REPORT} M.Stravinskas, V.Markevičiūtė, P.Bakutis

Key words: osteosarcoma, clinical case, diagnostic challenges. Summary

Osteosarcoma is one of the most common primary and aggressive bone tumor, which usually occurs in teenagers, although it has second growth peak in older people. Etiology of osteosarcoma is unclear. Thera are many predisposing risk factors, but the most common site of tumor in parts of the bone, which tend to grow the most and different peak of growth in teenager boys and girls may suggest that it could be highly associated with fast growing and hormonal activity. The most common symptom of osteosarcoma is pain at the site of the tumor, which usually manifest at night and usually it might be associated with previous trauma of the affected limb. It is important to have a precise diagnose of the tumor in order to treat it properly. It is recommended to have a MRI scan of the affected bone both with chest, abdomen, pelvic and spine CT scan to evaluate the spread of metastasis of the tumor. Up to 1970 the most popular way to treat osteosarcoma was amputation of the limb, although 5 year survival rate was not more than 10 percent. Nowadays 60-70 percent 5 year survival rate is reached with rapid evolvement of inductive and adjuvant chemotherapy which allows to treat osteosarcoma with limb salvaging surgery to be performed.

Correspondence to: pranciskus.bakutis@gmail.com

Gauta 2019-05-09 